\title{
HABAN CERAMICS IN THE COLLECTIONS OF THE SAVARIA MUSEUM*
}

\author{
Dénes DABÓcZI \\ Nádasdy Ferenc Museum \\ Várkerület 1, H-9600 Sárvár, Hungary \\ E-mail: daboczi.denes@nadasdymuzeum.hu
}

\begin{abstract}
The settlement and activity in Western Transdanubia of Anabaptists was first studied by Béla Iványi, law and cultural historian, then by Imre Katona, art historian. Building on the data they found in archives, this article presents the activity of the Habans in Vas County in the $16^{\text {th }}$ to $17^{\text {th }}$ centuries. A few details from inventories show what a rich store of their ceramics was to be found in aristocratic and noble castles and well-to-do town houses in the county. There is no longer any trace of that material. In all there are 17 pieces of Haban ceramics in the collections of Vas County museums. The 12 objects with dates and guild symbols presented here were made between 1676 and 1754. Presumably they are not the work of local Haban potters because their communities in Vas County ceased to exist after 1662. Only two objects have a reliably known provenance (Fig. 8 and 9); they can be attributed to the Odler workshop in Dejthe (Dechtice, Slovakia).
\end{abstract}

Keywords: dated Haban ceramics, Odler workshop, Western Transdanubian Anabaptists, migration of Anabaptists, Haban craftsmen, Batthyány family

\section{HABANS IN WESTERN TRANSDANUBIA}

The first person to deal with the settlement and activity of the Anabaptists in Western Transdanubia was Béla Iványi (1878-1964) law and cultural historian, in 1938-1944, as the archivist of the Prince Batthyány-Strattmann family of Körmend. More extensive research is associated with the name of Imre Katona (1927-2005), former art historian of the Museum of Applied Arts, who made a detailed study of their migration and work on the basis of the sources. We first encounter them in Western Transdanubia in Vas and Sopron Counties working on Renaissance construction projects for Tamás Nádasdy who welcomed all good artists and craftsmen regardless of religious denomination. According

*The version of this article was published in Hungarian language. Dabóczi Dénes: Habán kerámiák a Savaria Múzeum Gyűjteményében. Savaria, A Vas Megyei Múzeumok Értesitője 35. Szombathely, 2012. 371-389. 
to accounts of the period, between 1548 and 1562 Anabaptist cabinetmakers, glass makers, carpenters, coopers and tinsmiths worked in Sárvár, Léka (Lockenhaus, Austria), Sopronkeresztúr (Deutschkreutz, Austria) and Kapuvár. They lived in Sopron and travelled from there to the fortresses and castles to do work commissioned by the Palatine (KATONA 1974: 22, 2001: 17). On the Nádasdy estate they were often referred to as kalugyer (Greek priests) because they wore long black robes similar to those of Greek Orthodox priests (Katona 2001: 5). After the death of Tamás Nádasdy in 1562 there is no record of Anabaptist craftsmen here for a good three decades. Although Ferenc Nádasdy II, the famous "black bey", often opposed the Habsburgs, he did not employ Anabaptist craftsmen, or at least we do not know of such employment (KATONA 1965: 244, 1966: 576, 1969: I. 445, 1974: 22-24, 2001: 5 and 17). At the same time, according to a letter dated 20 December 1598, an Anabaptist doctor practised his profession in the court of the Zrínyi family and also appeared in Németújvár (Güssing, Austria) (IvÁNYi 1964: 17; KATONA 1966: 576, 1969: I. 445, 1974: 24, 2001: 63).

Besides the Nádasdy family, special mention must be made of the role played by the aristocratic Batthyány family: it is thought that there were already Anabaptists on their estates in the mid-16 $6^{\text {th }}$ century. It is not by chance that on 1 April 1600 King Rudolf ordered Ferenc Batthyány II to banish from his estates the sectarians living in Regede (Radkersburg, Austria) (IvÁnyi 1942: 134, 1964: 17; Katona 1965: 244, 2001: 63). After that date it is only from 1603 that we find a few families here. Then in 1617-1618 Anabaptist craftsmen fled to the Batthyány family from the estate of the Landau family in Zistersdorf, Upper Austria, but on the expiry of their contract they moved on to Nagylévárd (Vel'ké Levare, Slovakia) in Pozsony County (IvÁNyi 1964: 17; Katona 1965: 244-245, 1966: 576-577, 1969: I. 445, 1974: 24-26, 2001: 65).

After the Battle of White Mountain outside Prague on 8 November 1620, waves of Anabaptist refugees arrived, mainly on the estate of Pál Nádasdy in Csejte (Čachtice, Slovakia) and for economic reasons also on the estates of Prince Gábor Bethlen in Alvinc, Transylvania. Csejte played an important role: from here Anabaptists settled not only in Transylvania and Eastern Hungary but also on the estates of Pál Nádasdy in Vas County. After their presence in the $16^{\text {th }}$ century, we again find Anabaptists in the town of Sopron and in Sopron County in the mid- $17^{\text {th }}$ century on the estates of the Esterházy family (KATONA 1974: 57-59 and 60-62, 2001: 22-23, 26 and 28). They also immigrated in larger numbers to the Batthyány estate in 1622-1623 after the Battle of White Mountain. This was their largest wave of immigration to Western Transdanubia. Some arrived on the Batthyány estate already in 1622 from Maskowitz and Alexowitz in Moravia. According to an archive record, 48 Anabaptists came here in 1623 from the estates of Prince Johann in Jamnitz (Moravia) (IvÁNYi 1964: 18; KATONA 1966: 577, 1974: 26-27). There was a need for their work and skills as major castle building projects were beginning at that time in Körmend, Németújvár, Rohonc (Rechnitz, Austria) and Szalónak (Stadtschlaining, Austria). Most of the new arrivals lived in these towns, but others also settled elsewhere in villages. Their groups comprised 2-3 families, they did not live in strictly closed communities, but scattered in the villages (IvÁNyi 1964: 18; KATONA 1965: 244, 1966: 576-577, 2001: 65-68). The Anabaptists who arrived in 1622 were an exception: like the Haushabener of North-West Hungary, they lived in a settlement in Dávidháza (today part of Bajánsenye in 
the Örség region) surrounded by a stone wall, and went out from here to work on different parts of the estate. The leader of the Western Transdanubian Anabaptists was Lörinc Putz, a miller who lived in Németújvár; he did not belong to the "Serving Order", that is, he did not work on the estate but was supported by the community (KATONA 1965: 248-249, 252; 1974: 27-28, 2001: 65, 67). In Western Hungary the Anabaptists received only a site and permission to build their houses; they were not given agricultural land or meadow. On the Batthyány estate they were not bound by the urbarium, their activity was regulated by contracts signed with their employer, Ferenc Batthyány II, later Ádám Batthyány or one of their representatives for a period of 1-2 years, or a few months. There were both group and individual contracts, and these could be supplemented with various agreements (Katona 1965: 249-251, 1969: I. 446, 1974: 28-29, 2001: 67-68). One such agreement was made in 1623 between Ferenc Batthyány II and the Anabaptists (IváNYI 1964: 18-19), then in 1650 between Count Ádám Batthyány and Gabriel Praitensteiner, doctor and leader of the group. This also set out such demands as their freedom of religion, provision for the operation of their social facilities, and unusually also the right to collective administration of justice. ${ }^{1}$ The document also provided for the right of free departure if they were no longer needed. The count allowed the community to keep a teacher (priest, guardian), a caretaker, a shoemaker, a weaver and a schoolmaster (KATONA 1965: 249-251, 1969: I. 446, 1974: 28-29, 2001: 67-68).

The Anabaptist craftsmen, masters and officials were paid more than the average craftsmen. We know from the payment made in 1634 to the "serving orders" attached to the Németújvár castle that doctor Purgolt received 150 florins, the chief steward 40 florins, the potter 34 florins, the cutler 32 florins, the bailiffs 25 florins each, and Foltan the cellar master 25 florins. In addition they also received payments in kind. It was not by chance that this gave rise to jealousy among other craftsmen and the common people (Katona 1969: I. 452, 2001: 183-184). Ferenc Batthyány II was especially generous to the Anabaptists. In a letter written around 1619 he instructed his court judge, Bálint Boros, to send 20 florins to the New Christians, who were setting out for his estate from Vienna, a sum that was 5-6 times higher than the usual amount paid for travel expenses. At the same time he also had a small fortune, 32 florins paid to the millers (IvÁNYI 1964: 18; KATONA 1969: I. 449, 2001: 64). The account books for 1630-1640-1650 reveal that many of them worked on the estate for years and even decades. The miller Lörinc Putz for example, the leader of the New Christians, lived in Németújvár from 1623 until his death in 1632. The carpenter Kristóf Hyrzl from Neumühl, known simply as “carpenter Kristóf” Fig.d in the account books from 1623 to 1637, the chief steward Balthauser and the gardener Mihály von Brinn also worked for the Batthyány family for close to two decades (KATONA 1965: 245-247, 1966: 577-578, 1974: 27).

Despite the conversion of Ádám Batthyány to Catholicism in 1629, the New Christians were allowed to stay on the aristocrat's estates. However after 1662 no reference can be found to them in any written documents. In the mid-1 $7^{\text {th }}$ century Ana-

${ }^{1}$ According to Imre Katona the right to administer justice was limited (Katona 1979: 246, OL. P. 1322. Hg. Batthyány cs. 1t. A Batthyány cs. Körmendi Közp. Ig.-Szalonok vár urb. 164. II. 26. sz. 78-as rakt. sz. p. 50). 
baptists were to be found, although sporadically, on the estates of the Nádasdy and Esterházy families. In Sárvár, for example, in 1645 there is still mention of payment to the castle's miller and of a New Christian cutler. In 1656 Lord Chief Justice Ferenc Nádasdy III employed in his court a barber, or more precisely a surgeon, called Biehn (Pyen) (Katona 2001: 32). A few years later in 1660, for religious reasons there were no more Anabaptists. Pál Esterházy also recommended the expulsion of the Anabaptists from his estates in neighbouring Sopron County (Katona 2001: 196). From the 1660s their situation became increasingly more difficult, causing them to emigrate from Western Hungary, probably to Szobotist (Sobotište, Slovakia) and Nagylévárd.

\section{THE PRODUCTS OF HABAN POTTERS IN THE LIGHT OF INVENTORIES}

The greatest number of data on Haban potters in Western Transdanubia can be found in the accounts of the Batthyány family. According to the inventories, there was already an Anabaptist potter on their estates in 1622. From the 1630s we find a growing number of references to them. This could have been related to the construction of castles, given that new stoves were also needed in those buildings. Potters were exceptionally well paid. Hanz Prunner, the potter in Németújvár was paid 32 florins on 1641 and again in the following year. In Németújvár, in 1655 a "potter's house" was built in the castle, but it was only in 1656 that a potter moved in (KATONA 1969: I. 447; 1969: II. 603, 605; 2001: 187, 191). The inventories give a quite detailed picture on the work of the Haban craftsmen. We know from the inventories published by Imre Katona that there were 214 pieces of New Christian ceramics in the Batthyány castle in Rohonc on 1637, and 236 pieces in the Kovarcz (Kovarce, Slovakia) castle in 1660. They included plates with blue and white glaze, bowls, cups, pots with lids, a white casket with a coat-of-arms, earthenware box, a small blue, green and white barrel. The inventory of Dobra (Neuhaus am Klausenbach, Austria) castle drawn up in 1662-63 mentions a set of 11 "New Christian cups" (KATONA 1969: II. 602, 607-608; 2001: 186, 194-195). The most striking example of the great variety of the work of the Habans is the inventory made in 1635 of the "Rohonc Pharmacy House" (KatonA 2001: 184-185), in which many kinds of white, blue and green vessels are listed. Ferenc Nádasdy III also had his own pharmacy, where in 1669 New Christian vessels were mentioned together with various pieces of equipment (TAKÁTs 1907: 342, KRISZTINKOVICH 1960A: 37).

The Batthyány family had pottery made not only by local craftsmen but also by potters in North-West Hungary. In 1650 they commissioned New Christians in Szobotist to make ceramic wares for them. According to the accounts, this involved around 150 pieces with a value of 66.10 florins. This is quite a substantial number and value, particularly if we add to this the price of the spoons and knives with mother-of-pearl handles made by the cutlers: 76.50 florins (KATONA 1969: II. 604-605, 2001: 190; Ridovics 2008: 91). Together these orders amounted to 140.60 florins, ${ }^{2}$ which was a

${ }^{2}$ This is the sum that appears in the document. The writer of the inventory miscalculated, the sum should actually be 142.60 florins. 
considerable sum in those days. According to the documents, there were still Haban communities and a potter on the Batthyány estate at that time but despite this, they ordered ceramics from Szobotist, and this may also have happened in later years. The inventory made in 1682 of the belongings of Katalin Héderváry, widow of János Viczay in the Tömörd castle near Köszeg lists 73 New Christian dishes, bowls, plates, candlesticks, cups for fruit and soup (Ridovics 2008: 96). ${ }^{3}$ But it is not only in the homes and inventories of aristocrats that we find such objects. Haban ceramics also occur in bequest inventories of the lesser nobility in Vas County in the $18^{\text {th }}$ century. The estate inventory of Zsigmond Bottka and Anna Oreckij (Orczi, Orczy) drawn up in 1758 in the mansion in Söpte near Szombathely mentions one New Christian "iczés" (approx. 0.88 litre) jug and two jugs with pewter lids. ${ }^{4}$ The inventory of the late István Szecsődi in Egyházaszecsöd (now Magyarszecsőd) in 1746 mentions “[...] New Christian wares found in the above-mentioned cupboard [...]. ${ }^{5}$ Unfortunately, the inventory-takers did not list the objects in detail. Haban ceramics could have been and were in the possession of townspeople. In Szombathely in 1767, Ignác and István, the orphans of András Lakatos and his wife Klára Staim[merin] inherited, among numerous other things, two Anabaptist jugs with pewter lids. ${ }^{6}$ There are also much later, $20^{\text {th }}$ century data. According to an inventory made in 1919 by the internationally renowned palaeoarchaeologist Kálmán Miske, at the time director of the Vasvár County Museum, in the Sigray castle in Ivánc, item 299 comprised 12 "Walloon-type Haban plates" (ZsÁMBÉKY 1989: 120)? It was not only dishes that the Habans made for the estates but also tiled stoves, principally for the fortresses and castles of the Batthyány family. They were made in different colours for different rooms. In Németújvár, Rohonc, Dobra and Szalonak, the stoves in the rooms of women, namely the wives of Ferenc Batthyány and Ádám Batthyány, were white, while in the rooms of their husbands they were blue. The inventories also mention green tiled stoves. None of them has survived (KATONA 1969: I. 447, 2001: 186, 188-189).

\section{THE MUSEUM'S APPLIED ARTS COLLECTION, A FEW DATA ON THE COLLECTION OF HABAN CERAMICS}

The Savaria Museum's applied arts collection comprises close to 3000 objects. Most of these are $16^{\text {th }}$ to $20^{\text {th }}$ century Hungarian and Western European furniture, glassware, ceramics, textiles and artistic metal objects. The ceramics collection contains around 600-650 pieces. In 1958 - for reasons that are obscure - the Haban ceramics were trans-

${ }^{3}$ Khuen-Héderváry Archive, in Hédervár “Draskovich” Fascic. 72. Nr. 13. RadváNszky: 1986, I. 187, II. pp. $372-373$.

${ }^{4}$ Vas County Archive. Documents of the Assembly of Nobles of Vasvár County. Guardianship Documents. Inventories of estate. Inventory documents. Fasciculus. 2. Nr. 23.

${ }^{5}$ Vas County Archive. Documents of the Assembly of Nobles of Vasvár County. Guardianship Documents. Inventories of estate. Inventory documents. Fasciculus. 1. Nr. 36.

${ }^{6}$ Szombathely municipal documents, acta miscellaria. V. 102. C. Inventories of Szombathely Townspeople. Box No. 56.

${ }^{7}$ The inventory is in the documentation collection of the Savaria Museum Historical Collection, Inv. n. 20/1919. 
ferred to the inventory of the Ethnographic collection. Today that collection includes 1622 ceramic items, of which 15 are Haban and 120-130 post-Haban faience. Only a jug with a pewter lid from 1676 remained in the Applied Arts collection (Fig. 3).

Unfortunately, it is not known where many of the existing objects came from or where they were collected. In the case of the bottles from 1683 (Fig. 4), we know from the label glued on them that they were used as honey containers in Kukmér (Kukmír, Austria). The jug from 1754 with guild symbols and the inscription STEFANUS EGRI came from Monyorókerék (Eberau, Austria) (Fig. 12). An interesting feature of this item is that according to the label left inside it, in 1824 it was the jug of the Monyorókerék bakers' guild, although according to the guild symbols on it, it must have originally belonged to the tailors' guild. However, we have no information on whether it was used by the bakers as a guild jug. According to an old inventory book ${ }^{8}$, the Savaria Museum already had a number of Haban ceramics in its possession in the early $20^{\text {th }}$ century. A guild jug, item No. 48 came into the possession of the museum in 1909 as a gift. The entry reads as follows: "Halka Mihal 1679 guild jug", today it Fig.s as a guild jug (Fig. 1). According to a record made in 1926, the Haban dish dated 1703, inventory number 105, once belonged to the Dominican nuns in Szombathely. The dish is presumably the same one as the dish dated 1703 with the monogram HGS (Fig. 7). The catalogue of the 1934 Szombathely Art Historical and Cultural Historical Exhibition lists five Haban dishes that were in the possession of the museum at that time. They are all dated, with the years 1690, 1699, 1703, 1704 and 1706 (HoRvÁth 1934: 83, 85-86). These objects can be identified precisely as the dishes are still in the possession of the museum (Figs. 5-9). The same exhibition also included Haban ceramics from private collections. For example, Vilmos Eöry, a pharmacist and mayor of Sárvár, exhibited a jug with a lid, dated 1689 (HoRváth 1934: 28); its whereabouts are no longer known.

\section{HABAN CERAMICS}

With a few exceptions, the objects presented here are faience pieces with a white tin glaze inside and out, made between 1676 and 1754. Our museum has no objects from what Krisztinkovich has called the "pre-Haban" or "classical New Christian" first period of Haban ceramics (KRISZTINKOVICH 1968: 75). In an article published half a century ago he mentions and shows photos of pieces from this early period that were known to have existed in Vas County (KriszTinKovich 1960A: 33-50). Only four objects (Fig. 1-4) were made in the second period, 1620 to 1685 , that Krisztinkovich and Katona call the "pure Haban" style (KriszTinKOvich 1968: 75; Katona 1974: 92), and others refer to as "Hutterite Haban” (RÉTI 2011: 20). The jug of a wheelwrights' guild dated 1679 (Fig. 1) was probably made for an outside order; its inscription "HALKA MIHAL" indicates that it was probably made in one of the workshops in North-West Hungary. Its main motif, garlands of flowers and leaves in Renaissance taste between blue lines, and scale patterns arranged

8 Inventory Log of the Antiques Collection of Vasvár County Museum, Mediaeval and New Modern material. Applied art: 1. Ceramics and glass. pp. 210-226. The inventory log can be found in the Historical Collection of the Directorate of Vas County Museums, without a shelf mark. 
in a triangular form are typical Haban ornamentations. The same is true for the jug made in 1682 (Fig. 2), but here the scale pattern on the shoulder more closely resembles lace net. Something not found very often is that instead of the usual scale pattern on the place below the rim and above the foot, there is a row of plants of inverse direction. In addition to the painted decoration and motifs, the shape of the ceramics must also be mentioned: the bottle from 1683 for example (Fig. 4) can be traced back to types made by Western European Renaissance artistic metalworkers. It is well known that up to the mid- $17^{\text {th }}$ century New Christian potters were forbidden to portray buildings, animals and human Fig.s (KAtona 1984: 25, 119, 125). Around a third of the objects described and presented here have Fig.s in their decoration. The earliest of these is this bottle made in 1683, on which painted buildings can be seen.

Most of the blue, purple and green marbled Haban faience was made at the end of the $17^{\text {th }}$ century. The inventory of the Németújvár castle made in 1691 mentions seven "New Christian green variegated dishes" (KATONA 1974: 72). Our collection includes a blue and white marbled jug with a pewter lid; together with the date 1676 on the lid, the slightly squat shape indicates that it was made at a relatively early time (Fig. 3).

The majority of the ceramics were made in the third period, between 1685 and 1730/50. Many of them follow the traditions in shape and decoration. A good example of this is the plate with the monogram "PK" made in 1704 (Fig. 5); the cobalt blue concentric circles around the rim and in the well, the colourful tulip plant in the medallion, the inscriptions placed in a green laurel wreath and the shape itself are all reminiscent of the Late Renaissance. The same can be said of the plate with a blue tin glaze decorated with double circles and a white tulip plant in the well (Fig. 10). We find blue-glazed New Christian vessels relatively early, in the inventory of the Rohonc pharmacy in 1635 and of the Kovarc castle in 1660 (KATONA 2001: 184-185, 194).

Four bowls were made at the same time as the ceramics with the Late Renaissance style features mentioned above but in the blue and white European faience style, reminiscent of Chinese porcelain. The dish from 1699 (Fig. 6) and the one from 1703 with the monogram HGS (Fig. 7) are decorated with stylised buildings, birds, flowers and trees. While the decoration painted in cobalt blue is undoubtedly orientalising in character, dynamic individual brush lines can also be observed. The earlier dish, decorated by the painter with greater confidence and in higher quality, has the date 1699 in a green laurel wreath in the well. The year and the monogram HGS are placed on the rim of the bowl made in 1703. The latter is paler cobalt blue in colour, more detailed; the main motifs are supplemented with numerous tiny cloud and star-like forms ${ }^{9}$, but are less picturesque and improvised. Two other objects made during the same period are products of the Odler workshop in North-West Hungary. The Odler (Adler) family originally from Silesia, active from the end of the $17^{\text {th }}$ century to the end of the $19^{\text {th }}$ century, were researched in detail by Béla Krisztinkovich (KriszTINKOvich 1958: 137). He attributed objects in around 35-40

\footnotetext{
${ }^{9}$ Diána Radványi regards these star-like motifs as the later, stylised portrayal of a comet that appeared in 1702, painted in a relatively life-like way by the decorator of a bowl from 1702 in the Réti-Kulcsár collection. In her opinion, the observation of unusual natural phenomena of this kind, recording them in their chronicles and sometimes also portraying them, was integrally linked to the beliefs of the Anabaptists who proclaimed the approaching end of the world (RADVÁnYi 2011: 30, Fig. 438).
} 
public collections to Imre Odler, the family's most outstanding ceramist. ${ }^{10}$ Among them is a plate with the year 1690 and the monogram "M:R" of unknown provenance (KRISZTINKOVICH 1958: 139). The Ethnographic Collection of the Savaria Museum has a dish with the year 1690 and the monogram "M:R" (Fig. 8). The question arises whether the object believed to be in an unknown place and the object in the possession of the museum are the same. It is also possible that there could be other objects with the same monogram and for this reason "[...] it is only in rare cases that the identification of monograms without a coat-of-arms is unequivocal" (KRISZTINKOVICH 1968: 78), that is, they cannot be used with certainty for identification. At the same time we must note that the outstanding quality of the dish in the Szombathely collection and especially its painted ornamentation correspond to all the features that Béla Krisztinkovich held to be characteristic of the Odler workshop (KRISZTINKOVICH 1958: 135-136). The cobalt blue closed and open tulips on the rim without contour lines, the giant bulb forms, the likewise large, triangular leaf-like flowers, the fern fronds with leaflets diminishing in size, the scattered small wreaths, the winding garlands of leaves, flowers and berries are all characteristics of the Odler workshop. The decoration painted with great refinement is characteristically dynamic and spontaneous. Taking all this into account, our dish must be considered as the product of a workshop in North-West Hungary. Krisztinkovich also mentions a dish from 1706 in an unknown place in a public collection (KRISZTINKOVICH 1958: 139). It may be a coincidence, but there is also a dish from 1706 in Szombathely that can definitely be linked to the Odler workshop (Fig. 9). The decoration and motifs on the two bowls in Szombathely are very similar. The difference is in the style of the painting. The decorations on the dish from 1706 are more sketchy, less detailed. ${ }^{11}$

Because there is no photograph or other object suitable for identification of the two objects in unknown places, apart from the date and monogram, we cannot claim with full certainty that they are identical with the bowls in the Savaria Museum, but nor can it be excluded that they are in fact the same. In addition, we know that in 1650 the Batthyány family ordered New Christian ceramics from Szobotist (KATONA 1969: II. 604-605, 2001: 190; Ridovics 2008: 91). They may also have placed similar orders later. Nor can we ignore the fact that György Erdődy, chief treasurer, who was a patron of the Odlers also had

\footnotetext{
${ }^{10}$ According to Imre Katona not all the objects mentioned by Krisztinkovich are the work of Imre Odler or the workshop; if he does not reject this identification, he does question it (KatonA 1974: 131-132). At the same time more recent researches also adopt the position that these objects belong to a clearly definable style circle, generally known as the Odler workshop and its circle (HoRvÁth-KRISZTinkovich 2005: 122-124, 136-141, 163-165 and Ridovics 2008: 95). Layer also clearly distinguished this group of dishes that he described as highly decorative (LAYER 1927: XV. Abb. No. 7-18.).

${ }^{11}$ Among the objects published by Krisztinkovich, those closest in style and motifs - apart from the animal Fig.s - to the bowls in the Savaria Museum are a decorative bowl from around 1680 in a private collection, and three objects in the possession of the Museum of Applied Arts: a plate with the date 1683 and the monogram "ILL.C.L.", a decorative bowl from the year 1696 with the monogram "IAR.", and a decorative bowl from 1697 with the monogram "IAR" (KRIszTinkovich 1958: 138 and 140, Figs. 5, 8, 16, 18). The bowls dated 1696 and 1690 from the Barnabás Ruszinkó and the Starowic-Gyenes private collections shown in the Haban Myth exhibition held in the Museum of Applied Arts in 2007 are similar to the bowls in the Savaria Museum, particularly in the edge decorations (RÉTI 2007: 62-63, Figs. 94, 97). Also the bowl dated 1701 published by Layer, in the former Emanuel Lesner, later Krisztinkovich collection (LAYER 1927: 12).
} 
estates in Vas County, as did later descendants of this aristocratic family. For this reason, we cannot exclude the possibility that the two bowls (Fig. 8 and 9) came from North-West Hungary to Vas County through the Erdődy or perhaps the Batthyány family directly after they were made, or later through the art trade. The dishes decorated with buildings and birds (Fig. 6 and 7) were also probably made in North-West Hungary, but it cannot be excluded that they could have been made in Western Hungary. It is, however, certain that all four dishes have been in the possession of the Savaria Museum for eight decades, as they also Fig.d in the Szombathely Art Historical and Cultural Historical Exhibition held in 1934.

The decorator chose to paint a profane theme on a jug. On the front a crowned eagle with a large head has the date 1716 in a heart-shaped medallion on its chest and below it a man fills wine from a giant yellow barrel. He is dressed in the typical Hungarian costume of the period (Fig. 11). This small Fig. can actually be regarded as a miniature costume image of the type common at the turn of the $17^{\text {th }}$ to $18^{\text {th }}$ century.

The greatest problem in connection with the Haban ceramics in the museums of Western Hungary and, more particularly, of Vas County, is the question of provenance. We have certain or almost certain knowledge of where they were made for only a few of our objects. The problem is aggravated by the fact that the Nádasdy and the Erdődy families had estates in both Western Transdanubia and Northern Hungary and the ceramics in our museum could in theory have been made in both regions. In addition there is the fact that the Batthyány family also had ceramics made to order in Szobotist (KATONA 1969: II. 604-605, 2001: 190; Ridovics 2008: 91). Moreover, we have no information after 1662 on the presence of New Christian potters in Vas County, and the earliest objects in our museum date from 1676. Nevertheless, it is possible that after leaving the community and converting to Catholicism, independent craftsmen may have continued to operate in this part of the country too, ${ }^{12}$ but this cannot be either proved or disproved. At present, because the inscriptions and monograms have not been identified, we cannot even name the persons who ordered them. Moreover, in many cases we do not know the way in which the objects entered the ceramics museum. Further research may be able to help in establishing the provenance of our objects.

\section{LITERATURE}

Horvath, J. E. - Krisztinkovich, Maria

2005: A History of Haban Ceramics - A Private View. Vancouver B. C., 2005.

HoRváth Tibor Antal - RADNAi Rezső

1934: Szombathelyi Müvészettörténeti és Kultúrtörténeti Kiállitás Tárgymutatója. [Catalogue of the Szombathely Art Historical and Cultural Historical Exhibition.] Martineum Könyvnyomda R. T. Szombathely. 1-88.

IVÁNYi Béla

1942: A körmendi levéltár Memorabiliái. [Memorabilia in the Körmend Archive.] Körmendi Füzetek 2. Körmend 1942. "RÁBAVIDÉK" nyomda és lapkiadóvállalat. 1-179.

${ }^{12}$ Katona also refers to this, noting that in this case they could have worked for the local people (KATONA 1973: 241). 
1964: Az anabaptisták vagy újkeresztények Nyugat-Magyarországon. [The Anabaptists or New Christians KATONA Imre in Western Hungary.] Református Egyház 1964. 14. 16-20.

1965: Habán emlékek Vas megyében. [Haban Relics in Vas County.] Savaria, A Vas megyei Múzeumok Értesitöje [Savaria. Bulletin of the Vas County Museums.] 1965. 3. Szombathely 1966. 237-256.

1966: A Vas megyei keramikus hagyományok és a magyarszombatfai kerámiagyár. I. rész. [Ceramic Traditions in Vas County and the Magyarszombatfa Ceramics Factory. Part I.] Vasi Szemle Vol. XX. 1966. 4. 573-582.

1969: Szemelvények a Batthyány-Levéltár anabaptista emlékeiből. [Selection of Anabaptist Relics in the Batthyány Archive.] Part I. Vasi Szemle Vol. XXIII. 1969. 3. 445-452. Part II. Vasi Szemle Vol. XXIII. 1969. 4. 601-608.

1973: A késő-habán kerámia és a XVIII. századi fajansz néhány kérdése. [A Few Questions of Late Haban Ceramics and $18^{\text {th }}$ Century Faience.] Müvészettörténeti Értesitö Vol. XXII. 1973. 4. 233-253.

1974: A habán kerámia Magyarországon. [Haban Ceramics in Hungary.] Képzőmüvészeti Alap Kiadóvállalata, Bp. 1-222.

1979: Újabb adatok a habánok Vas megyei szerepléséhez. [New Data on the Role of Habans in Vas County.] Savaria, A Vas megyei Múzeumok Értesitöje [Savaria, Bulletin of the Vas County Museums] 1973-1974. 7-8. Szombathely 1979. 245-255.

1984: Habán müvészeti emlékek Magyarországon. [Haban Artistic Relics in Hungary.] Múzsák, Budapest. 1-240.

2001: Habánok Magyarországon. [Habans in Hungary.] Gesta Könyvkiadó Kft. 1-198.

KRISZTinKovich Béla

1958: “NOBILIS AMPHORARIUS MAGISTER.” Müvészettörténeti Értesitő. 1958. 134-141.

1960A: Habán emlékek Sopronban és környékén. [Haban Relics in Sopron and District.] Soproni Szemle 1960. Vol. XIV. 3, 33-50.

1960B: Az Iparmúvészeti Múzeum újkeresztény fajanszai. [Anabaptist Faience in the Museum of Applied Arts.] Az Iparmüvészeti Múzeum Évkönyvei [Yearbook of the Museum of Applied Arts] III-IV. 1959. Képzőművészeti Alap Kiadóvállalata, Budapest 1960. 137-156.

1968: Habán "inkunábulumok" nyomában. [In Search of the Haban "incunabula".] Müvészettörténeti Értesitö 1968. XVII. 1-2. 73-79.

LAYER, Karl Dr.

1927: OBERUNGARISCHE HABANER FAYENCEN. Friedrich Ernst Hübsch Verlag/Berlin Leipzig und Wien. $1-70$.

RADVÁNSZKY Béla

1986: Magyar családélet és háztartás a XVI. és XVII. században. [Family Life and Household in Hungary in the $16^{\text {th }}$ and $17^{\text {th }}$ Centuries] Budapest 1879-1880. I. 187. II. 372-373.

RADVÁNYI Diána

2011: A habán kerámia tárgyak jellemzői. [Characteristics of Haban Ceramic Objects.] In: RADVÁNYI Diána - Rе́тI László. A habánok kerámiamüvészete. [Ceramic Art of the Habans.] Novella Könyvkiadó, Debrecen. 27-33.

RÉTI László

2011: A szépséggé égetett hit. [Belief Fired to Beauty.] In: RaDványi Diána - RéTI László. A habánok kerámiamüvészete. [Ceramic Art of the Habans.] Novella Könyvkiadó, Debrecen. 15-23.

2007: (Ed.): Habán mitosz 1593-1738. Magyar magángyüjtemények kincsei. [Haban Myth 1593-1738. Treasures from Hungarian Private Collections.] Exhibition Catalogue of the Museum of Applied Arts, Budapest. 1-84.

Ridovics Anna

2008: A habán kerámia a 17. században. [Haban Ceramics in the 17 $7^{\text {th }}$ Century.] In Mıkó Árpád (ed): Mátyás király öröksége. Késöreneszánsz müvészet Magyarországon 16-17. század. [Legacy of King Matthias. Late Renaissance Art in Hungary $16^{\text {th }}-17^{\text {th }}$ Centuries.]. Art Boksz Pauker Nyomda MNG, Budapest. 86-97. 
TAKÁTS Sándor

1907: A magyar patika. Müveltségtörténeti Közlemények. [The Hungarian Pharmacy. Cultural Historical Papers.] Századok 1907. Vol. XLI. 4. 332-343.

ZsÁMBÉKY Mónika

1989: Két Vas megyei kastély mükincsállománya 1919-ben. [The Art Treasures of Two Castles in Vas County in 1919.] VASI SZEMLE XLIII. Vol. 1989. 112-122.

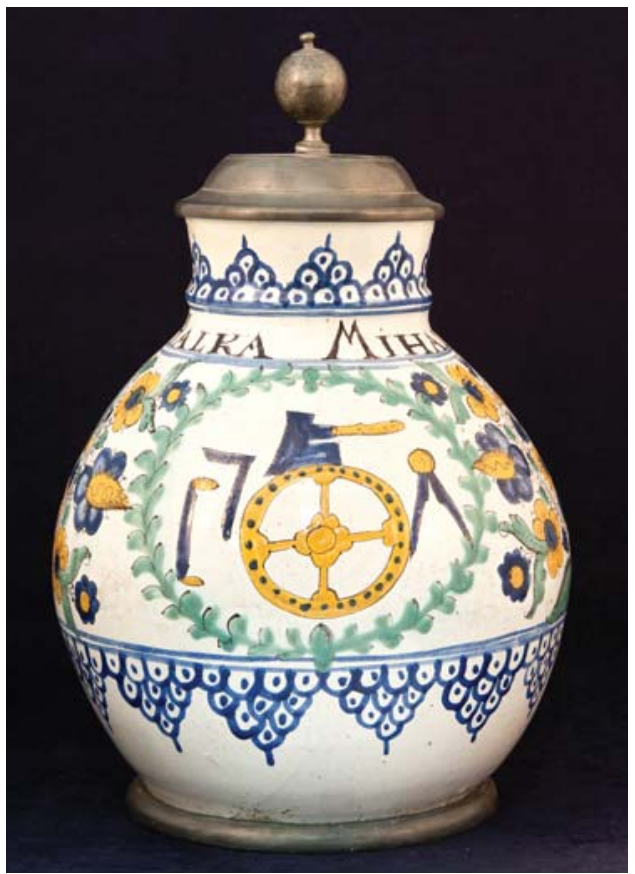

Fig. 1. Jug 1679 with the inscription "HALKA MIHAL", Probably North-West Hungary

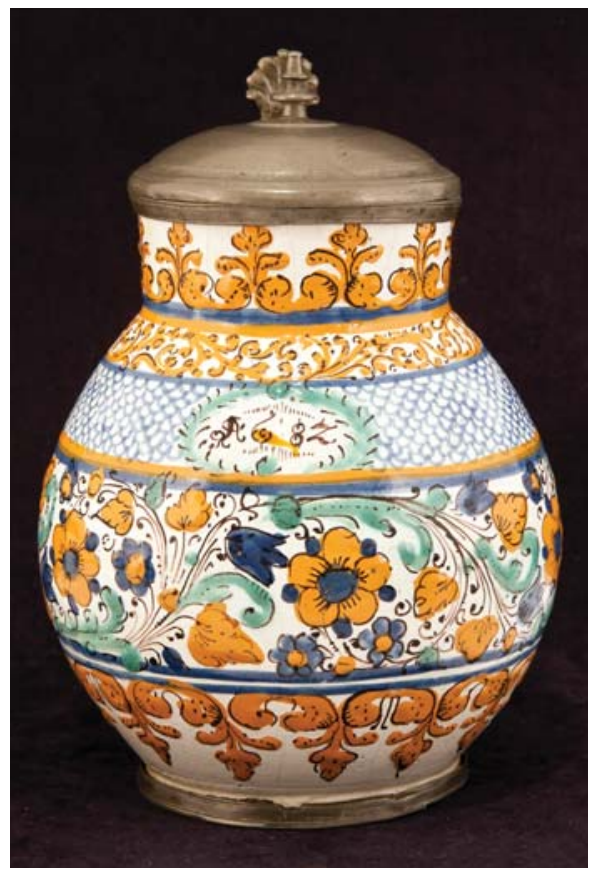

Fig. 2. Jug 1682 (Smidt Museum, Szombathely) 


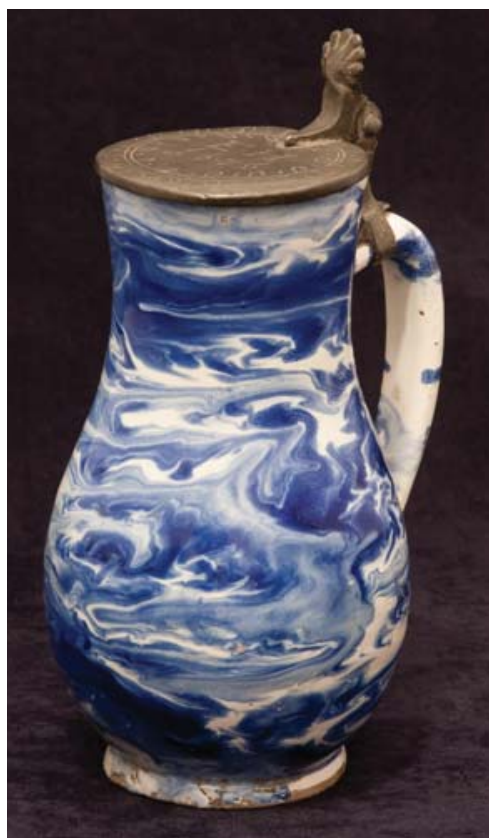

Fig. 3. Pear-shaped jug, 1676

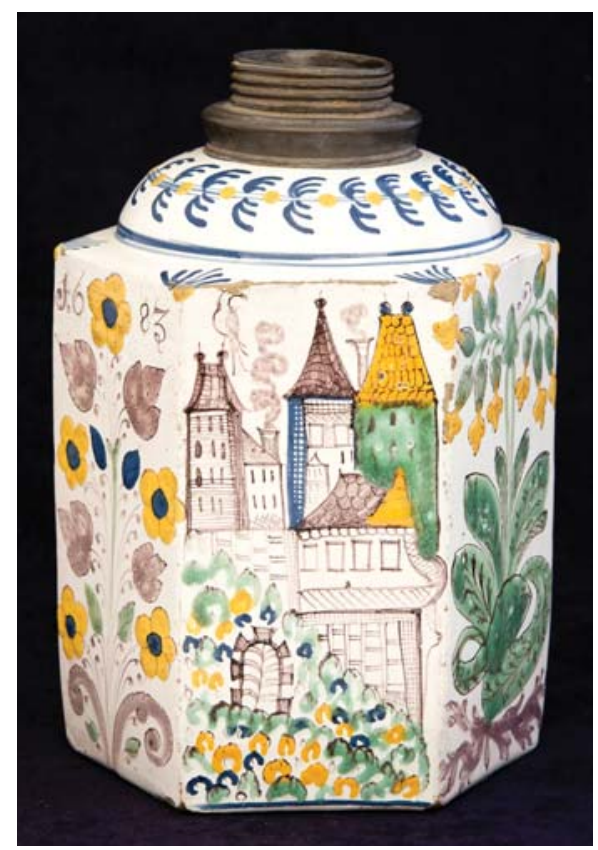

Fig. 4. Six-sided bottle, 1683

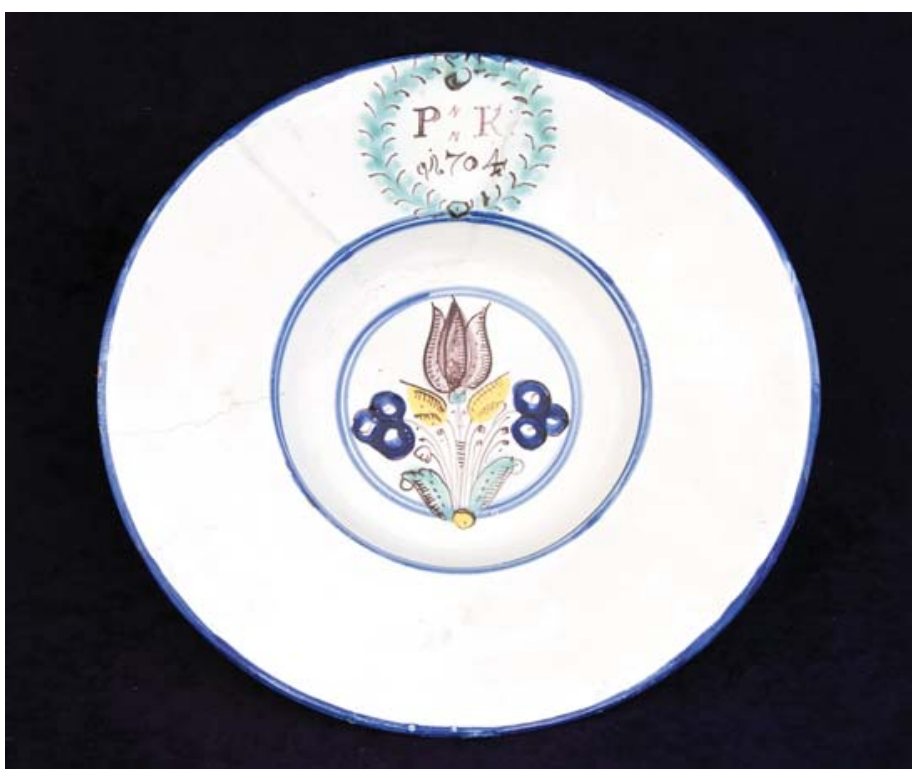

Fig. 5. Dish 1704 with the monogram PK 


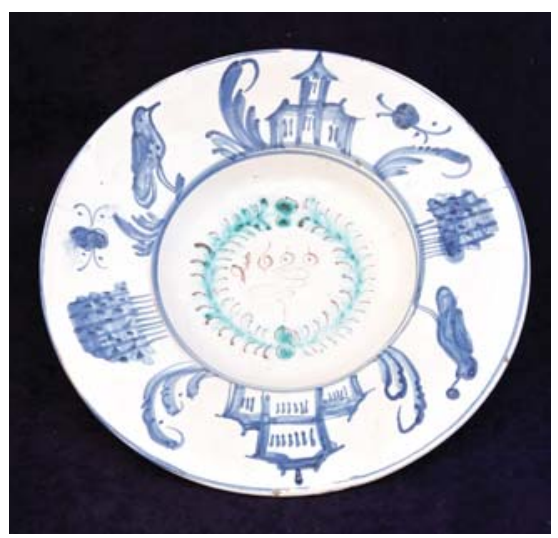

Fig. 6. Dish, 1699. North-West Hungary?

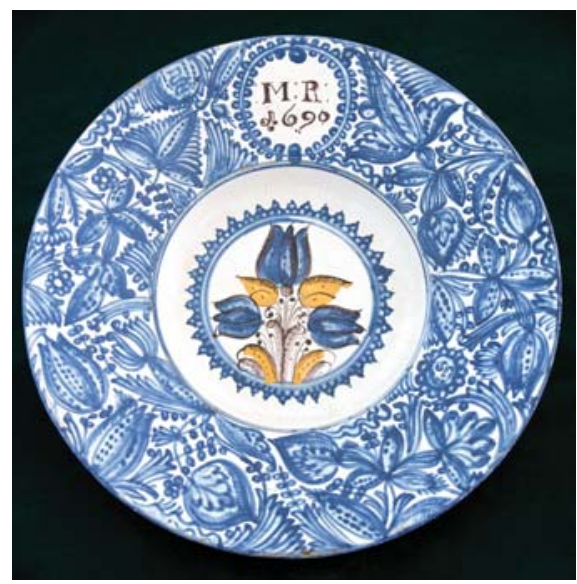

Fig. 8. Dish, 1690 with monogram MR. Odler workshop, Dejthe (Dechtice, Slovakia)

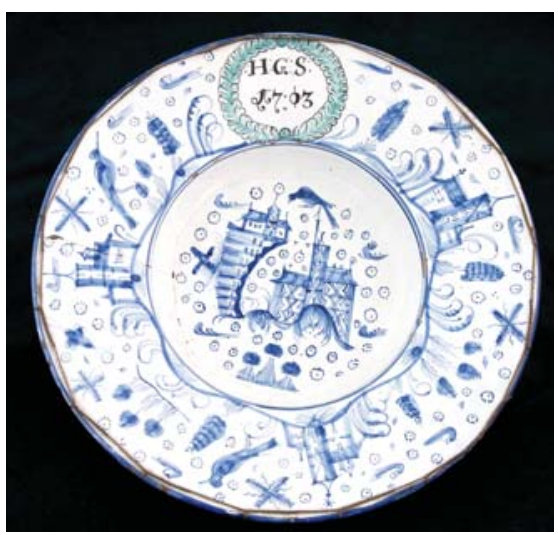

Fig. 7. Dish, 1703 with the monogram "HGS". North-West Hungary?

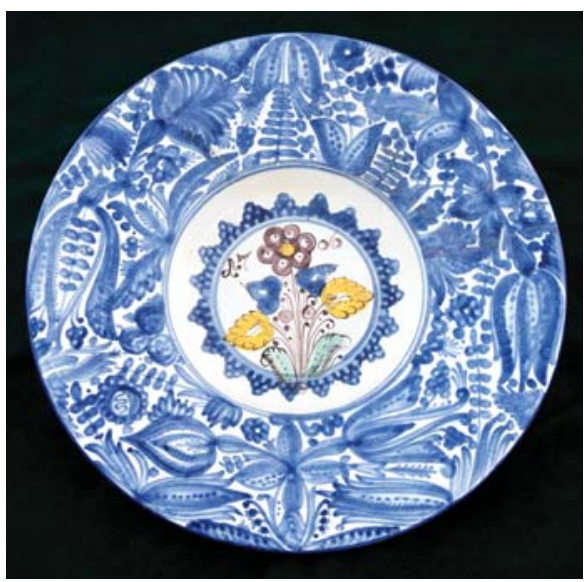

Fig. 9. Dish, 1706. Odler workshop, Dejthe (Dechtice, Slovakia) 


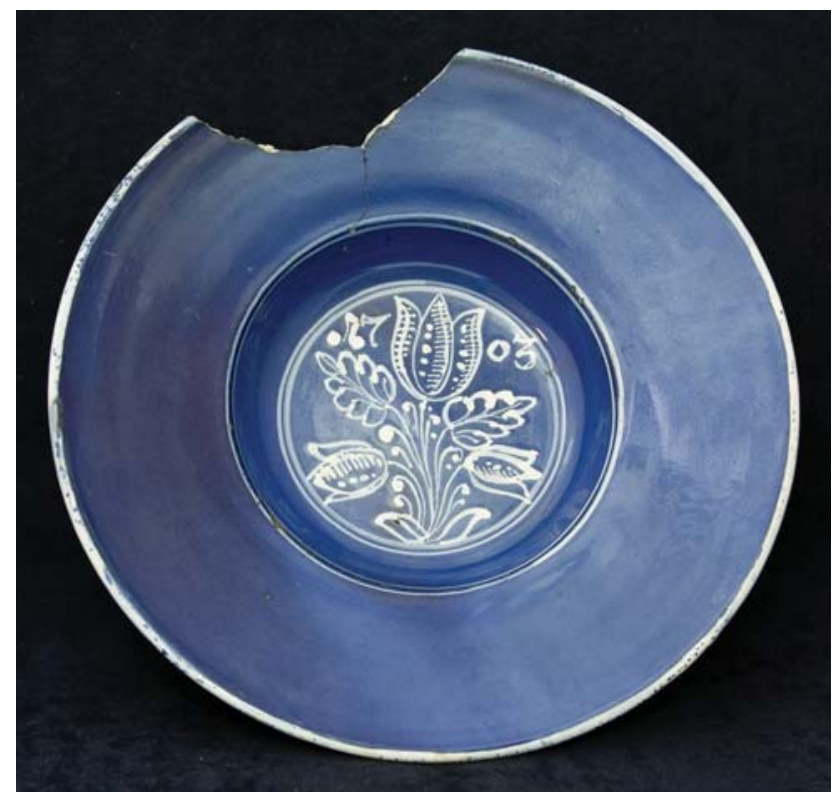

Fig. 10. Dish, 1703

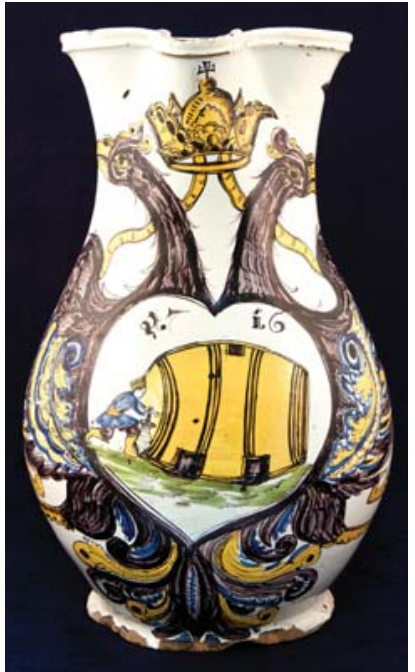

Fig. 11. Jug, 1716

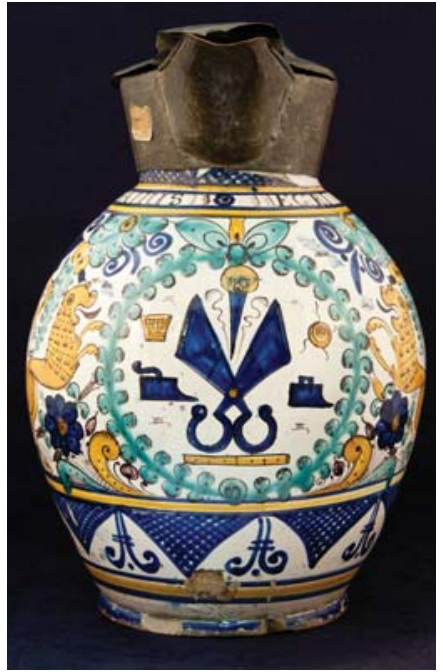

Fig. 12. Jug, 1754 with the inscription "STEFANUS EGRI"

Photos by Péter Móricz 